\title{
Endothelin-A Receptor Blockade in Porcine Pulmonary Hypertension
}

\author{
NAMASIVAYAM AMBALAVANAN, JOSEPH B. PHILIPS, III, ARLENE BULGER, SUZANNE OPARIL, AND \\ YIU-FAI CHEN
}

\author{
Departments of Pediatrics [N.A., J.B.P., A.B.], and Medicine [S.O., Y-F.C.], University of Alabama at \\ Birmingham, Birmingham, AL 35233 U.S.A.
}

\begin{abstract}
Endothelin-1 can cause pulmonary vasoconstriction via endothelin-A $\left(\mathrm{ET}_{\mathrm{A}}\right)$ receptor activation. We hypothesized that $\mathrm{ET}_{\mathrm{A}}$ blockers (EMD 122946 and BQ 610) would reduce hypoxiainduced (HYP) but not group B streptococcal infusion (GBS)induced pulmonary hypertension in a juvenile whole animal model. Pulmonary hypertension was created by exposing chronically instrumented piglets to HYP $(n=12)$ or heat-killed GBS $(n=11) . \mathrm{ET}_{\mathrm{A}}$ blockade was produced by increasing bolus doses of EMD122946 or BQ 610. Pulmonary arterial pressure (PAP), systemic arterial pressure (SAP), left atrial pressure, central venous pressure, and cardiac output were continuously measured. Pulmonary and systemic vascular resistance indices (PVRI and SVRI) were calculated. HYP doubled PAP and PVRI. Both $\mathrm{ET}_{\mathrm{A}}$ blockers decreased PAP and PVRI in a dose-dependent manner in HYP, with high doses decreasing PVRI to baseline and reducing PAP by $50 \%$. GBS also doubled both PAP and PVRI. EMD 122946 did not change PAP or PVRI in GBS, although BQ 610 markedly increased PVRI ( $>100 \%$ increase with $0.15 \mathrm{mg} / \mathrm{kg}$ ) and showed a trend toward increasing PAP. Both models showed minimal $(<25 \%)$ changes in SAP or SVRI.
\end{abstract}

ABSTRACT

Neither ETA blocker changed baseline hemodynamics in the absence of HYP or GBS. $\mathrm{PaO}_{2}$ did not change with GBS but decreased with $\mathrm{BQ} 610 . \mathrm{ET}_{\mathrm{A}}$ receptor blockade attenuated hypoxic, but not GBS induced pulmonary hypertension. BQ 610 worsened PVRI and oxygenation in the GBS model. Differences in response to $\mathrm{ET}_{\mathrm{A}}$ blockade in pulmonary hypertension may be seen depending on the etiology (hypoxia versus infectionassociated), and the specific $\mathrm{ET}_{\mathrm{A}}$ antagonist used. (Pediatr Res 52: 913-921, 2002)

CI, cardiac index

\section{Abbreviations}

ET-1, endothelin-1

GBS, group B streptococcus

NO, nitric oxide

PAP, mean pulmonary arterial pressure

PPHN, persistent pulmonary hypertension of the newborn

PVRI, pulmonary vascular resistance index

SAP, mean systemic arterial pressure

SVRI, systemic vascular resistance index
Persistent pulmonary hypertension of the newborn (PPHN) affects over 10,000 infants every year in the United States (1) and is associated with considerable morbidity and mortality. Prenatal hypoxia may predispose to PPHN (1). Disorders such as bronchopulmonary dysplasia are also associated with elevated pulmonary pressures and pulmonary vascular remodeling in infants (2). Endothelin-1 (ET-1) is a 21-amino acid polypeptide with strong vasoactive properties that vary depending on age (3), vascular bed, dosage (4), and species (5). ET-1 acts via two different receptors in the vascular bed, $\mathrm{ET}_{\mathrm{A}}$ and $\mathrm{ET}_{\mathrm{B}}$. In the pulmonary artery, $\mathrm{ET}_{\mathrm{A}}$ receptors mediate vasoconstriction and are found on vascular smooth muscle cells, while $\mathrm{ET}_{\mathrm{B}}$ receptors that are mostly located on endothelial cells mediate vaso-

Received September 4, 2001; accepted June 21, 2002.

Correspondence: Namasivayam Ambalavanan M.D., 525 New Hillman Building, UAB Station, Birmingham, AL 35233-7335 U.S.A.; e-mail: ambal@sprynet.com

Presented in part at the Pediatric Academic Societies' Meeting, Baltimore, Maryland, U.S.A., April-May 2001.

DOI: 10.1203/01.PDR.0000037141.16642.C6 dilation (6). There is substantial evidence that ET-1 is elevated in neonates, infants (7-9), and older children (10) with pulmonary hypertension, and is a marker of disease severity. Animal studies have also indicated that ET-1 may play a role in the pathogenesis of neonatal pulmonary hypertension due to hypoxia (11), meconium aspiration (12), and increased pulmonary blood flow (13). Therefore, there has been interest in endothelin receptor blockade as a possible therapy for pediatric pulmonary hypertension.

Our previous studies have shown that selective $\mathrm{ET}_{\mathrm{A}}$ receptor antagonists attenuate acute hypoxic pulmonary hypertension $(14,15)$ and reverse chronic hypoxic pulmonary hypertensive vascular and cardiac changes $(15,16)$ in adult animals. However, the pulmonary circulation of the neonate and young infant is structurally and functionally different compared with the adult pulmonary circulation. Animal studies have demonstrated that prophylaxis with a nonselective ET receptor antagonist in the piglet model attenuates pulmonary vasoconstriction during acute hypoxemia and reoxygenation (17). The efficacy 
of selective $\mathrm{ET}_{\mathrm{A}}$ receptor antagonists have not been fully investigated when given after the onset of the stimulus (hypoxia- or infection- induced) causing pulmonary hypertension (i.e.), as therapy rather than prophylaxis.

Hypoxia is more often a result of, rather than a predisposing factor for pulmonary hypertension in the neonate and young infant. Infection, such as with group B streptococci (Streptococcus agalactiae), meconium aspiration syndrome, and congenital diaphragmatic hernia are common causes of pulmonary hypertension in the neonatal period. The roles of endothelin and of endothelin receptor blockade in infection-associated pulmonary hypertension are unknown.

In the present investigation, we used a chronically instrumented 3-4 week old piglet model to evaluate the effects, and therefore the potential therapeutic role, of two selective $\mathrm{ET}_{\mathrm{A}}$ receptor antagonists (EMD 122946 and BQ 610) in two different models (hypoxia-and group B streptococcal- induced) of acute pulmonary hypertension. We hypothesized that the $\mathrm{ET}_{\mathrm{A}}$ blockers would reduce hypoxia-induced but not group B streptococcal infusion-induced pulmonary hypertension in a juvenile whole animal model. Our rationale for this hypothesis was that ET-1 was probably involved in hypoxia-induced but not in GBS-mediated pulmonary hypertension, which our prior studies had shown to be thromboxane-mediated (18).

\section{METHODS}

The research protocols were approved by the Institutional Animal Care and Use Committee of the University of Alabama at Birmingham, and all care and handling of the animals was in accordance with National Institutes of Health [NIH] guidelines.

\section{Surgical Preparation}

Three week old piglets were mechanically ventilated through an endotracheal tube using standard anesthesia equipment and $0.5-1.5 \%$ halothane. A left thoracotomy was performed between the second and third ribs and the pericardium opened. The ductus arteriosus was confirmed to be closed in all animals. An 8 or $10 \mathrm{~mm}$ precalibrated ultrasonic flow transducer (Transonic Systems, Ithaca, NY, U.S.A.) was affixed around the main pulmonary artery, and two 5 Fr. Catheters were inserted into the main pulmonary artery and left atrium, respectively, using purse-string sutures. Aortic and inferior vena caval catheters were placed through the left femoral artery and vein, respectively, through a left groin incision. All catheters and the pulmonary artery flow transducer cable were passed through s.c. tunnels to a left flank incision and stored in a pouch secured to the skin with nonabsorbable monofilament sutures. The chest and groin incisions were then closed. A sweater of tubular gauze was fitted to the animal to prevent dislodgement of the pouch. After completion of the surgery, animals were provided appropriate analgesia and postoperative care and allowed to recover for 3-4 d. Catheters were flushed daily with normal saline containing 10 units $/ \mathrm{mL}$ heparin, and 5 $\mathrm{mg} / \mathrm{kg}$ of gentamicin and $50 \mathrm{mg} / \mathrm{kg}$ of ampicillin were injected daily through the femoral venous catheter for infection prophylaxis. This chronically instrumented piglet model is not strictly equivalent to a human neonate even if the surgery were to be done in the immediate newborn period, as the recovery period following surgery (3-4 d) assures that the animal does not have a transitional circulation. However, we have observed in this model that the pattern of hemodynamic responses at 3-4 wk of age is similar to that in 1-wk-old piglets (data not shown).

\section{Measurements}

The flow transducer was connected to a T101 Ultrasonic Blood Flowmeter (Transonic Systems) and all catheters were connected to precalibrated pressure transducers (Spectramed P23XL, Oxnard, CA, U.S.A.). Systemic (SAP), pulmonary artery (PAP), left atrial (LAP), and central venous pressures (CVP), as well as mean pulmonary artery flow were continuously monitored using physiologic recorders (Gould-Brush 2400S, Oxnard, CA, U.S.A.). Cardiac index was calculated as pulmonary artery flow/body weight. Systemic (SVRI) and pulmonary vascular resistance indices (PVRI) were calculated as (SAP-CVP)/cardiac index and (PAP-LAP)/cardiac index, respectively.

\section{Drug Preparation}

EMD 122946 was kindly provided by Merck (Merck KgaA, Darmstadt, Germany). $50 \mathrm{mg}$ of EMD 122946 was dissolved in $20 \mathrm{~mL}$ of sterile $0.9 \%$ saline solution to yield a $2.5 \mathrm{mg} / \mathrm{mL}$ final concentration. BQ 610 was purchased from Peptides International, Inc (Peptides International, Inc, Louisville, KY). Five $\mathrm{mg}$ of BQ 610 was dissolved in $1 \mathrm{~mL}$ of DMSO and subsequently diluted to $50 \mathrm{~mL}$ with sterile $0.9 \%$ saline, to yield a final concentration of $0.1 \mathrm{mg} / \mathrm{mL}$.

\section{Experimental Protocols}

Experiments were performed on sedated nonintubated piglets after three to four days of recovery from surgery. Piglets were sedated with diazepam $1-2 \mathrm{mg} / \mathrm{kg}$ and pentobarbital 5-10 $\mathrm{mg} / \mathrm{kg}$, and subsequently received smaller doses every $30-60$ min if excessive movement was observed.

Hypoxia-induced pulmonary hypertension. The head of the piglet was placed in the inner hood of a double-hood apparatus. The inner hood was constructed of Plexiglas (10 inch diameter; Olympic Oxyhood; Olympic Medical, Seattle, WA, U.S.A.) and the outer hood was made of plastic sheeting $(12 \times 12 \times$ 10 inch; NOVA tenthouse oxygen tent; Nova Health Systems Inc, Utica, NY). A double-hood apparatus was used as the gas concentrations in the inner hood were more stable and easily regulated. Oxygen and nitrogen, adjustable by flowmeter from $0-15 \mathrm{~L} / \mathrm{min}$, were delivered from individual cylinders to yield the flow into the inner hood, which the animal breathed. A $\mathrm{NO} / \mathrm{N}_{2}$ gas mixture (800 ppm $\mathrm{NO}$ and balance $\mathrm{N}_{2}$; Ohmeda PPD Inc, Liberty Corner, NJ, U.S.A.) could also be blended as desired with the oxygen/nitrogen mixture. A NO/NO2 sensor (Range 0.05 to 99.9 ppm; SensorNOx, Sensormedics BV, 3720 AG Bilthoven, The Netherlands) and an oxygen analyzer continuously monitored the $\mathrm{NO}, \mathrm{NO}_{2}$, and $\mathrm{O}_{2}$ concentrations in the inner hood. A suction apparatus attached to the outer hood, 
in combination with the $\mathrm{NO} / \mathrm{NO}_{2}$ sensor (which worked by suction of sample gas past a sensor) suctioned gases at approximately $8-10 \mathrm{Lpm}$ to prevent expired gas accumulation in the inner hood. The oxygen concentration was adjusted to $20 \%$ to $22 \%$ in the inner hood (oxygen at $2 \mathrm{Lpm}+$ nitrogen at $8 \mathrm{Lpm}$ ) and baseline recordings were obtained for $15 \mathrm{~min}$. Hypoxic conditions were then created in the hood by decreasing the oxygen concentration to $10 \%$ by increasing the nitrogen flow (9 Lpm) and decreasing oxygen flow (1 Lpm).

Once the pressure readings were stable after $15 \mathrm{~min}$ of hypoxia exposure, increasing doses of EMD $122946(0.02$, $0.04,0.14,0.4,1.6 \mathrm{mg} / \mathrm{kg})$ or BQ $610(0.01,0.04,0.10,0.10$ $\mathrm{mg} / \mathrm{kg}$ ) were given i.v. every $10-15 \mathrm{~min}$, once the pressure tracings were stable for at least five minutes following a dose. This dosing pattern allowed us to evaluate the effect of a cumulative dose of $0.02,0.06,0.2,0.6$, and $2.0 \mathrm{mg} / \mathrm{kg}$ for EMD 122946 and $0.01,0.05,0.15$, and $0.25 \mathrm{mg} / \mathrm{kg}$ for BQ 610 . These doses and dosing intervals were based on personal communications on pharmacokinetic data (Merck, Darmstadt, Germany), and pilot studies of i.v. dosing of these agents in this model that demonstrated a rapid onset of action within a few minutes, a plateau within $10 \mathrm{~min}$, with the effect gradually tapering off over a few hours. After administration of the final dose of the $\mathrm{ET}_{\mathrm{A}}$ receptor antagonist, once the pressure tracings stabilized, NO was administered at $20 \mathrm{ppm}$ into the inner hood for $10 \mathrm{~min}$. The NO was then discontinued and the oxygen concentration returned to $20 \%$ to $22 \%$ for $15-20 \mathrm{~min}$ as the final step in this protocol. NO was administered to evaluate if inhaled NO was able to produce any additional reduction in pulmonary hypertension following the use of endothelin receptor antagonists.

Hypoxic pulmonary hypertension was produced in twelve piglets, six of which were then exposed to EMD 122946 and six to BQ 610.

Group B streptococcal-induced pulmonary hypertension. GBS Type Ib Strain 501, which was originally isolated from the cerebrospinal fluid of an infant with late-onset sepsis and meningitis, was grown to late logarithmic phase in a chemically defined medium for 4 to $5 \mathrm{~h}$ (18). The cultures were heat killed at $80^{\circ} \mathrm{C}$ for $30 \mathrm{~min}$, washed twice in PBS and resuspended in PBS to an OD equivalent to $1 \times 10^{9}$ colony-forming units (cfu)/mL (19).

After baseline recording for 10-15 min and ensuring stability of the recordings, the GBS preparation was infused at 2 $\mathrm{mL} / \mathrm{kg} / \mathrm{h}$ with a syringe pump (Harvard Apparatus, South Natick, MA, U.S.A.) for 10 minutes. If there was a less than $50 \%$ increase in pulmonary arterial pressures, the infusion rate was increased to $3 \mathrm{~mL} / \mathrm{kg} / \mathrm{h}$. After $10-15 \mathrm{~min}$, once stable tracings were attained, increasing doses of EMD 122946 or BQ 610 were given, followed by $\mathrm{NO}$ exposure as in the hypoxic pulmonary hypertension protocol. A total of 11 piglets were used for this experiment, 5 of which were given EMD 122946 and 6 given BQ 610 .

In additional experiments, four piglets were exposed to hypoxia (without $\mathrm{ET}_{\mathrm{A}}$ receptor blockade or other drugs) for 90 min as controls. Also, two piglets received $\mathrm{ET}_{\mathrm{A}}$ receptor blockade without exposure to hypoxia or GBS infusion, to evaluate effects of $\mathrm{ET}_{\mathrm{A}}$ receptor blockade on normal hemody- namics. Four piglets received pretreatment to L-NAME (Sigma Chemical Co., St. Louis, MO, U.S.A.) before hypoxia or GBS exposure, to evaluate if $\mathrm{ET}_{\mathrm{A}}$ receptor blockade would remain effective in the presence of NO synthase inhibition.

\section{Blood Samples}

Heparinized blood samples were drawn from the systemic arterial catheter at five time points for arterial blood gas analysis and ET-1 assay: at baseline, once a stable plateau of PAP had been achieved with hypoxia or GBS, 15 min after infusion of the final dose of EMD 122946 or BQ 610, $15 \mathrm{~min}$ after beginning $\mathrm{NO}$ administration, and $15 \mathrm{~min}$ after removal of hypoxia/GBS infusion and discontinuation of NO (re-base). Temperature-corrected $\mathrm{pH}$ and blood gases were measured with a Synthesis 25 model blood gas analyzer (Instrumention Laboratory, Lexington, MA, U.S.A.).

Samples for ET-1 assay were centrifuged at $1000 \times g$ at $4^{\circ} \mathrm{C}$ for $5 \mathrm{~min}$ to separate the plasma. The plasma was then frozen at $-80^{\circ} \mathrm{C}$ until assayed by ELISA (Parameter, R\&D Systems, Minneapolis, MN, U.S.A.). Before assay, an extraction procedure for ET-1 was used. One $\mathrm{mL}$ of plasma and $1.5 \mathrm{~mL}$ of extraction solvent (acetone: $1 \mathrm{~N} \mathrm{HCl}$ :water in 40:1:5 proportion) were mixed and centrifuged for $20 \mathrm{~min}$ at $2000 \times \mathrm{g}$ in a refrigerated centrifuge at $4^{\circ} \mathrm{C}$. One $\mathrm{mL}$ of the supernatant was collected and dried in a centrifugal evaporator. The pellet was then reconstituted in $0.2 \mathrm{~mL}$ of the sample diluent provided with the ELISA system to yield a 5-fold final concentration. The minimal detectable ET-1 level with this ELISA was 1 $\mathrm{pg} / \mathrm{mL}$. The cross-reactivity of this assay with big endothelin was $<1 \%, 45 \%$ with ET-2, and 14\% with ET-3 (manufacturer data). All samples were processed as a single batch.

\section{Statistical Analysis}

Hemodynamic variables, arterial blood gases, $\mathrm{pH}$, and plasma ET-1 levels were compared over time within each study group by repeated measures ANOVA. If significant differences were found by repeated measures ANOVA, multiple comparisons by Dunnett's test (for hemodynamic variables, in comparison to hypoxia/GBS values) or Tukey's test (all pair-wise comparisons, for blood gases and ET-1 plasma levels) were performed. A $p$ value of $<0.05$ was considered statistically significant. Values are expressed as means \pm SE.

\section{RESULTS}

The piglets were similar at baseline, all being female piglets of 3-4 wk of age weighing 4-8 kg. Sedation of these chronically instrumented piglets did not significantly affect systemic or pulmonary hemodynamics.

\section{Hemodynamics}

Hypoxia model. EMD 122946. Hypoxia increased PAP from $15 \pm 1$ to $30 \pm 3 \mathrm{~mm} \mathrm{Hg}$, and PVRI from $0.07 \pm 0.01$ to 0.122 $\pm 0.02 \mathrm{~mm} \mathrm{Hg} / \mathrm{mL} / \mathrm{min} / \mathrm{kg}$. Starting from a cumulative dose of $0.06 \mathrm{mg} / \mathrm{kg}$, EMD 122946 significantly decreased PAP (24 \pm $3 \mathrm{~mm} \mathrm{Hg})$ and PVRI $(0.09 \pm 0.02 \mathrm{~mm} \mathrm{Hg} / \mathrm{mL} / \mathrm{min} / \mathrm{kg})$ in a dose-dependent manner. At the maximal dose of $2 \mathrm{mg} / \mathrm{kg}$, 
EMD 122946 decreased PAP to $20 \pm 3 \mathrm{~mm} \mathrm{Hg}$ and PVRI to $0.07 \pm 0.01 \mathrm{~mm} \mathrm{Hg} / \mathrm{mL} / \mathrm{min} / \mathrm{kg}$. The subsequent addition of NO decreased PAP and PVRI even further (to $14 \pm 2 \mathrm{~mm} \mathrm{Hg}$ and $0.05 \pm 0.01 \mathrm{~mm} \mathrm{Hg} / \mathrm{mL} / \mathrm{min} / \mathrm{kg}$, respectively). The decline in PAP and PVRI with EMD 122946 and NO was significantly greater than the changes seen in control animals exposed to hypoxia for a similar time duration, but without administration of $\mathrm{ET}_{\mathrm{A}}$ blockers or NO. Control animals exposed to hypoxia for $1 \mathrm{~h}$ had a $14 \pm 3 \%$ drop, whereas EMD 122946 led to a 34 $\pm 5 \%$ fall (at a dose of $2 \mathrm{mg} / \mathrm{kg}$ ), and BQ 610 to a $27 \pm 7 \%$ fall (at a dose of $0.25 \mathrm{mg} / \mathrm{kg}$ ) in the PAP from the peak hypoxic value $(p<0.05)$. The corresponding declines in PVRI were similar (20 $\pm 7 \%$ in controls, $43 \pm 3 \%$ for EMD 122946, and $36 \pm 8 \%$ for BQ 610) (Fig. 1).

No significant changes were seen in systemic arterial pressure, although systemic vascular resistance decreased with hypoxia (from $0.45 \pm 0.04$ at baseline to $0.35 \pm 0.05 \mathrm{~mm}$ $\mathrm{Hg} / \mathrm{mL} / \mathrm{min} / \mathrm{kg}$ with hypoxia) and stayed lower through the rest of the exposure and subsequent return to room air. The decrease in systemic vascular resistance was inferred from an increase in cardiac index (from $197 \pm 11$ at baseline to $242 \pm$ $14 \mathrm{~mL} / \mathrm{min} / \mathrm{kg}$ with hypoxia) without any change in systemic arterial pressure. The elevated cardiac index also did not
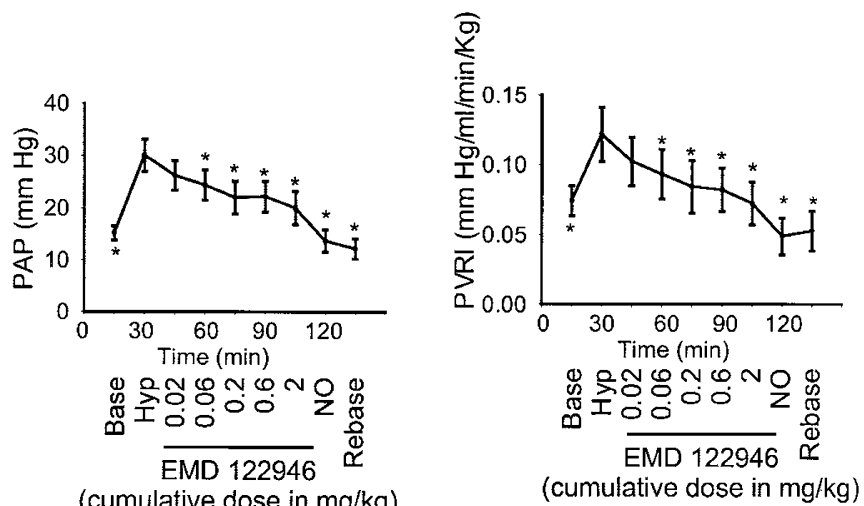

cumulative dose in $\mathrm{mg} / \mathrm{kg}$ )
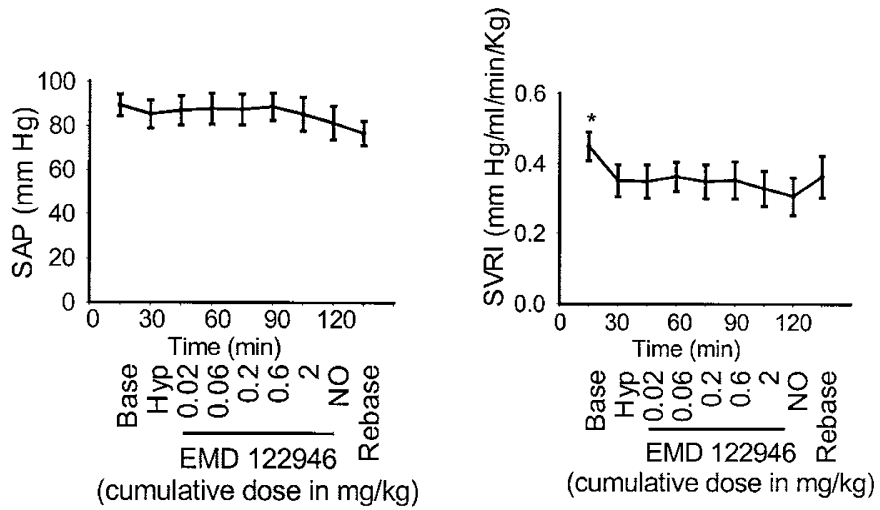

Figure 1. Effects of EMD 122946 in increasing bolus doses on pulmonary arterial pressures (PAP), pulmonary vascular resistance index (PVRI), systemic arterial pressures (SAP), and systemic vascular resistance index (SVRI) in hypoxia-induced pulmonary hypertension in piglets. BASE = baseline; $\mathrm{HYP}=$ exposure to $10 \%$ oxygen; $\mathrm{HYP}+\mathrm{NO}=$ exposure to $10 \% \mathrm{O}_{2}+20 \mathrm{ppm}$ $\mathrm{NO}$; Rebase $=$ return to room air. (mean $\pm \mathrm{SEM}, n=6, p<0.01$ by RM ANOVA; $* p<0.05$ vs hypoxia value). change significantly through the rest of the hypoxic exposure or return to baseline.

$B Q 610$. The hemodynamic responses to $\mathrm{BQ} 610$ in the hypoxia model were very similar to those of EMD 122946 . BQ 610 at $0.25 \mathrm{mg} / \mathrm{kg}$ was roughly equipotent to $2 \mathrm{mg} / \mathrm{kg}$ of EMD 122946 in regard to effects on pulmonary arterial pressures and pulmonary vascular resistances. Again, the changes in PAP and PVRI seen with BQ 610 in the hypoxia model were significantly greater than in control animals exposed to hypoxia but not given BQ 610. A hypoxia-induced increase in systemic vascular resistance and cardiac index was also seen in this model, similar to that observed with EMD 122946 (Fig. 2).

GBS model. EMD 122946. GBS infusion increased PAP from $16 \pm 1$ to $34 \pm 3 \mathrm{~mm} \mathrm{Hg}$, and PVRI from $0.07 \pm 0.01$ to $0.14 \pm 0.02 \mathrm{~mm} \mathrm{Hg} / \mathrm{mL} / \mathrm{min} / \mathrm{kg}(p<0.05)$. EMD 122946 did not affect PAP or PVRI significantly, even at the maximal dose of $2 \mathrm{mg} / \mathrm{kg}$ (PAP of $36 \pm 5 \mathrm{~mm} \mathrm{Hg}$ and PVRI of $0.18 \pm$ $0.05 \mathrm{~mm} \mathrm{Hg} / \mathrm{mL} / \mathrm{min} / \mathrm{kg}$ ). The subsequent addition of $\mathrm{NO}$ decreased PAP and PVRI (PAP of $29 \pm 7 \mathrm{~mm} \mathrm{Hg}$ and PVRI of $0.15 \pm 0.06 \mathrm{~mm} \mathrm{Hg} / \mathrm{mL} / \mathrm{min} / \mathrm{kg}$ ), but these changes were not statistically significant. However, NO without prior pretreatment with ETA blockers or L-NAME, decreased PAP and PVRI to baseline in this GBS model (data not shown) (Fig. 3).

GBS infusion and subsequent EMD 122946 did not change systemic vascular resistance or cardiac index significantly,
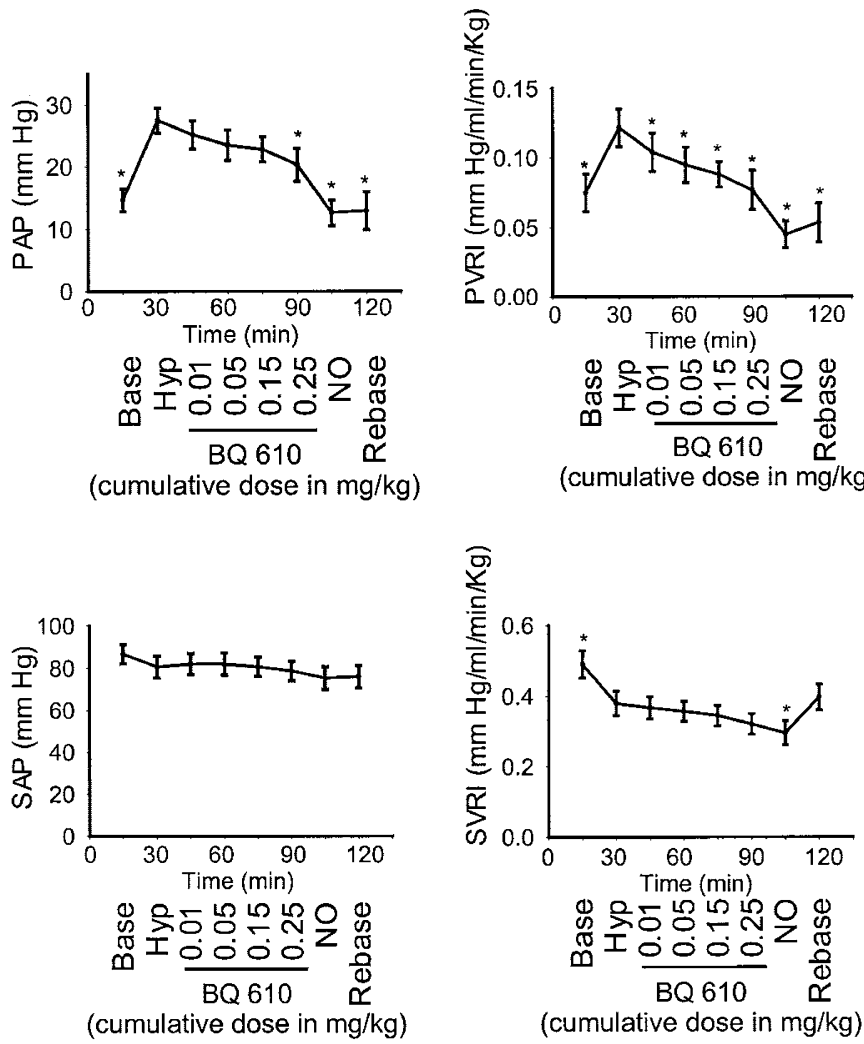

Figure 2. Effects of BQ 610 in increasing bolus doses on pulmonary arterial pressures (PAP), pulmonary vascular resistance index (PVRI), systemic arterial pressures (SAP), and systemic vascular resistance index (SVRI) in hypoxia-induced pulmonary hypertension in piglets. $\mathrm{BASE}=$ baseline; $\mathrm{HYP}=$ exposure to $10 \%$ oxygen; $\mathrm{HYP}+\mathrm{NO}=$ exposure to $10 \% \mathrm{O}_{2}+20 \mathrm{ppm} \mathrm{NO}$; Rebase $=$ return to room air. (mean \pm SEM, $n=6, p<0.01$ by RM ANOVA; $* p<0.05$ vs hypoxia value). 

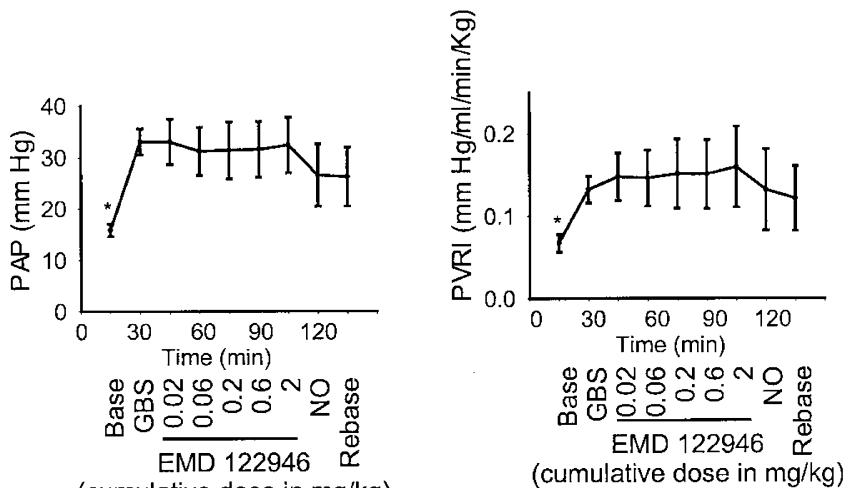

(cumulative dose in $\mathrm{mg} / \mathrm{kg}$ )
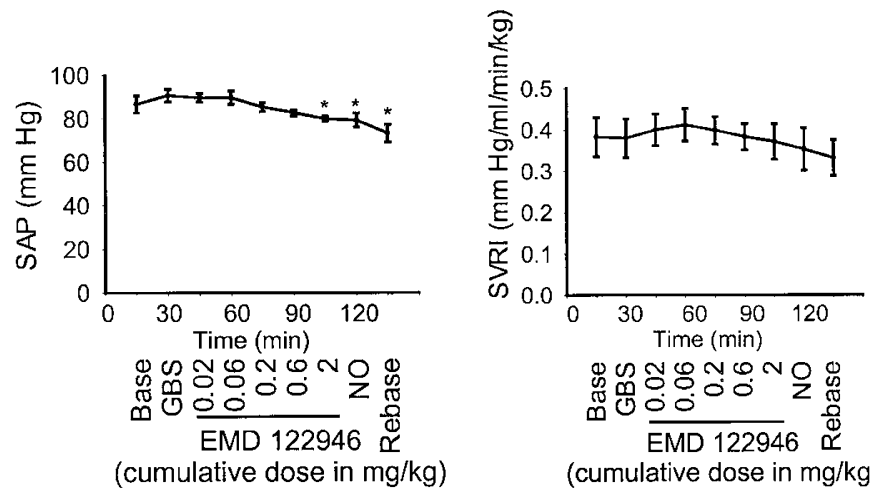

Figure 3. Effects of EMD 122946 in increasing bolus doses on pulmonary arterial pressures (PAP), pulmonary vascular resistance index (PVRI), systemic arterial pressures (SAP), and systemic vascular resistance index (SVRI)in GBS-induced pulmonary hypertension in piglets. BASE = baseline; $\mathrm{GBS}=$ exposure to GBS infusion; GBS + NO $=$ exposure to $\mathrm{GBS}+20 \mathrm{ppm}$ NO; Rebase $=$ off GBS (mean \pm SEM, $n=5, p<0.01$ by RM ANOVA; * $p<0.05$ vs GBS value).

although there was a minor fall in systemic arterial pressure $(<20 \%)$ with $2 \mathrm{mg} / \mathrm{kg}$ EMD 122946 that persisted through the subsequent $\mathrm{NO}$ administration and discontinuation of GBS that was statistically significant.

$B Q$ 610. GBS infusion increased PAP from $15 \pm 1$ to 34 $\pm 2 \mathrm{~mm} \mathrm{Hg}$, and PVRI from $0.07 \pm 0.005$ to $0.19 \pm 0.03$ $\mathrm{mm} \mathrm{Hg} / \mathrm{mL} / \mathrm{min} / \mathrm{kg}(p<0.05)$. BQ 610 increased PVRI $(0.42 \pm 0.15 \mathrm{~mm} \mathrm{Hg} / \mathrm{mL} / \mathrm{min} / \mathrm{kg}$ at a dose of $0.25 \mathrm{mg} / \mathrm{kg} ; p$ $<0.05)$ and showed a trend toward an increase in PAP (44 $\pm 7 \mathrm{~mm} \mathrm{Hg}$ at $0.25 \mathrm{mg} / \mathrm{kg} ; p<0.1)$. The increase in PVRI with a lesser change in PAP indicates impaired cardiac output (as PVRI $=(\mathrm{PAP}-\mathrm{LAP}) /$ cardiac index, and LAP was relatively constant). The subsequent addition of NO decreased PAP and PVRI (PAP of $34 \pm 5 \mathrm{~mm} \mathrm{Hg}$ and PVRI of $0.29 \pm 0.08 \mathrm{~mm} \mathrm{Hg} / \mathrm{mL} / \mathrm{min} / \mathrm{kg}$ ), but these changes were not statistically significant. It must again be noted that NO without prior pretreatment with ETA blockers, decreased PAP and PVRI to baseline in this GBS model (data not shown) (Fig. 4).

GBS infusion and subsequent BQ 610 did not change systemic arterial pressure, cardiac index, or systemic vascular resistance significantly.
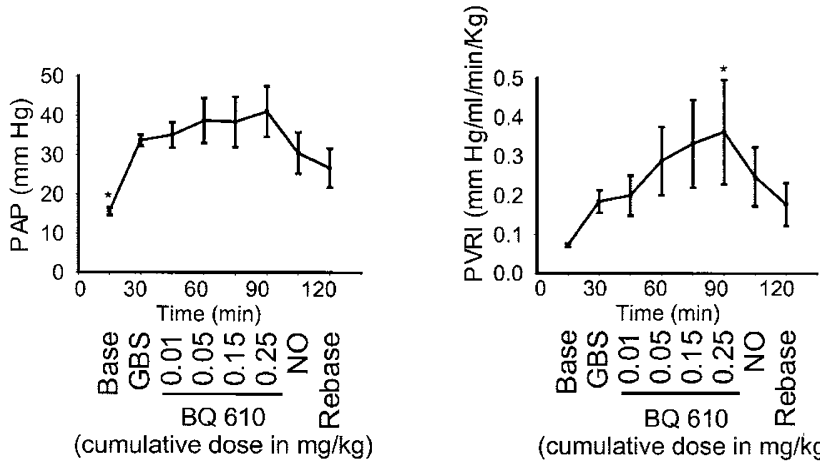

(cumulative dose in $\mathrm{mg} / \mathrm{kg}$ )
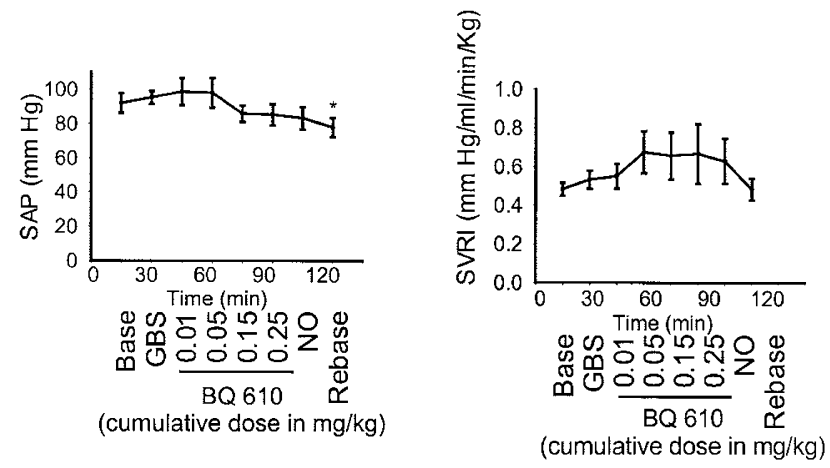

Figure 4. Effects of BQ 610 in increasing bolus doses on pulmonary arterial pressures (PAP), pulmonary vascular resistance index (PVRI), systemic arterial pressures (SAP), and systemic vascular resistance index (SVRI) in GBSinduced pulmonary hypertension in piglets. BASE = Baseline; GBS = exposure to GBS infusion; GBS $+\mathrm{NO}=$ exposure to $\mathrm{GBS}+20 \mathrm{ppm} \mathrm{NO}$; Rebase $=$ off GBS (mean \pm SEM, $n=6, p<0.01$ by RM ANOVA; ${ }^{*} p<$ 0.05 vs GBS value).

\section{Additional Experiments: Pretreatment with L-NAME before Hypoxia or GBS}

Animals treated with L-NAME to decrease NO production before the onset of hypoxia led to an immediate and sustained increase in systemic and pulmonary arterial pressures (increase of PAP from $15 \pm 1$ to $44 \pm 11 \mathrm{~mm} \mathrm{Hg}, p<0.01)$ and vascular resistances (increase of PVRI from $0.08 \pm 0.01$ to 0.39 $\pm 0.15 \mathrm{~mm} \mathrm{Hg} / \mathrm{mL} / \mathrm{kg} / \mathrm{min}, p<0.05)$. Subsequent hypoxia did not further increase pulmonary arterial pressures (PAP $45 \pm 9$ $\mathrm{mm} \mathrm{Hg}, p=0.97$ versus prior level) or vascular resistances (PVRI $0.42 \pm 0.16 \mathrm{~mm} \mathrm{Hg} / \mathrm{mL} / \mathrm{kg} / \mathrm{min}, p=0.9$ versus prior level), suggesting that acute hypoxia causes pulmonary hypertension primarily by reducing NO production. EMD 122946 at the maximal dose $(2 \mathrm{mg} / \mathrm{kg})$ did not cause a statistically significant change in pulmonary arterial pressures during hypoxic exposure if L-NAME had been administered (PAP $36 \pm$ $9 \mathrm{~mm} \mathrm{Hg}, p>0.05$ ).

Animals treated with L-NAME to decrease NO production before the onset of GBS infusion also had an immediate and sustained increase in the systemic and the pulmonary arterial pressures (increase of PAP from $16 \pm 1$ to $33 \pm 12 \mathrm{~mm} \mathrm{Hg}$, $p<0.05$ ) and vascular resistances (increase of PVRI from 0.07 \pm 0.01 to $0.23 \pm 0.10 \mathrm{~mm} \mathrm{Hg} / \mathrm{mL} / \mathrm{kg} / \mathrm{min}, p<0.05)$. Subsequent GBS infusion further increased pulmonary arterial pressures (from $33 \pm 12 \mathrm{~mm} \mathrm{Hg}$ to $53 \pm 2 \mathrm{~mm} \mathrm{Hg}, p<0.05$ ) and vascular resistance (from $0.23+0.10$ to $0.47+0.03 \mathrm{~mm} \mathrm{Hg}$ / $\mathrm{mL} / \mathrm{kg} / \mathrm{min}, p<0.05$ ), indicating that GBS infusion causes 
pulmonary hypertension by mechanisms other than by reducing NO production. EMD 122946 again did not significantly change hemodynamics.

\section{Arterial Blood Gases}

Hypoxia model. Hypoxia led to lower $\mathrm{Po}_{2}$ and tachypnea, with resulting mild respiratory alkalosis $(\mathrm{pH} 7.50-7.52 /$ $\mathrm{PO}_{2} 25-26$ torr $/ \mathrm{PCO}_{2} 31-32$ torr $/ \mathrm{HCO}_{3} 25-26 \mathrm{mEq} / \mathrm{SaO}_{2} 52 \%$ to $55 \%$ ). Hypoxia followed by $\mathrm{ET}_{\mathrm{A}}$ blockade and the subsequent NO administration did not significantly change blood gases (Tables 1 and 2).

GBS model. The baseline values were similar to those for the hypoxia model. GBS infusion did not significantly change blood gas parameters. Unlike the hypoxia model, there was no respiratory alkalosis, and the degree of hypoxemia was also lesser in magnitude and statistically not significant. BQ 610, but not EMD 122946, was associated with a lower $\mathrm{Po}_{2}$ value (54 \pm 5 torr, $p<0.05$ ). Subsequent $\mathrm{NO}$ administration increased $\mathrm{Po}_{2}(68 \pm 7$ torr $)$ in the $\mathrm{BQ}$ 610 model.

\section{Plasma Endothelin Levels}

In the hypoxia model, ET-1 levels were not elevated with hypoxia, but were higher with $\mathrm{ET}_{\mathrm{A}}$ blockade and subsequent $\mathrm{NO}$, and returned to baseline at the end of the experiment. In the GBS model, a trend was noted toward increased levels with $\mathrm{ET}_{\mathrm{A}}$ blockade, and again on return to baseline ( $p=0.17$ by ANOVA) (Table 3).

\section{DISCUSSION}

In the present study, we have shown that endothelin-A receptor blockade attenuates acute hypoxia-induced, but not GBS-induced pulmonary hypertension in a porcine whole animal model. This observation supports the rationale for our hypothesis that ET-1 plays a role in the pathogenesis of hypoxia-induced, but not acute GBS-induced pulmonary hypertension. To our knowledge, this is the first evaluation of endothelin receptor antagonists in GBS-induced pulmonary hypertension. We also found that differences in physiologic effects exist between two apparently selective $\mathrm{ET}_{\mathrm{A}}$ blockers. BQ 610 increased pulmonary vascular resistance, and tended to increase pulmonary arterial pressures in the GBS model, although EMD 122946 did not have these effects. Differences in response to $\mathrm{ET}_{\mathrm{A}}$ blockade in infants with pulmonary hypertension may therefore be seen depending on the etiology (hypoxia versus infection-associated), and the specific $\mathrm{ET}_{\mathrm{A}}$ antagonist that is used.

A limitation of our study is the use of 3-4 week old piglets necessitated by the chronically instrumented model, which may have different hemodynamic responses compared with piglets in the first few days of life. Therefore, our model may not be strictly comparable to human neonates. However, acutely instrumented piglets in the 1st wk of life have been previously shown in our laboratory to have a similar pattern of hemodynamic response to hypoxia and GBS infusion. Another limitation is that our piglets were spontaneously hyperventilating in the hypoxia model, resulting in acute respiratory alkalosis and possibly alkalosis-mediated vasodilation. However, the $\mathrm{pH}$ and $\mathrm{P}_{\mathrm{CO} 2}$ did not change much once the peak of hypoxic pulmonary hypertension had been attained. Therefore, the effects of $\mathrm{ET}_{\mathrm{A}}$ blockade must be considered in view of the existing $\mathrm{pH}$ (around 7.50) and spontaneous hyperventilation.

Acute hypoxia-induced pulmonary hypertension is generally considered to be the result of a combination of decreased $\mathrm{NO}$ production (20) and increased ET-1 release (15). Our results showed that L-NAME (a nonselective NO synthase inhibitor) increased PAP and PVRI, and that subsequent GBS, but not hypoxia, further increased PAP and PVRI. This indicates that GBS acts by mechanisms other than decreasing NO production. Earlier investigations from our laboratory have indicated that increased thromboxane synthesis is responsible for GBSinduced pulmonary hypertension, as thromboxane synthesis inhibition with dazmegrel returns PAP and PVRI in the GBS model to control values (18). Other investigators have also shown that GBS permits thromboxane analog induced pulmonary vasoconstriction but inhibits ET-1 induced vasoconstriction (21). This may however be a simplistic explanation for

Table 1. Arterial blood gas analysis in the hypoxia/GBS models with EMD 122946

\begin{tabular}{|c|c|c|c|c|c|}
\hline & Base & Нyp & +EMD & $+\mathrm{NO}$ & Re-base \\
\hline \multicolumn{6}{|c|}{ EMD-hypoxia model } \\
\hline $\mathrm{pH}$ & $7.45 \pm 0.01$ & $7.52 \pm 0.02$ & $7.50 \pm 0.07$ & $7.48 \pm 0.07$ & $7.43 \pm 0.07$ \\
\hline $\mathrm{PaO}_{2}$ & $91 \pm 4^{*}$ & $26 \pm 2$ & $27 \pm 2$ & $27 \pm 2$ & $75 \pm 4^{*}$ \\
\hline $\mathrm{HCO}_{3}$ & $28 \pm 1$ & $26 \pm 2$ & $24 \pm 3$ & $21 \pm 3$ & $24 \pm 3$ \\
\hline \multirow{2}{*}{$\mathrm{SaO}_{2}$} & $97 \pm 0.4^{*}$ & $55 \pm 5.4$ & $57 \pm 6.3$ & $56 \pm 4.7$ & $94 \pm 2 *$ \\
\hline & Base & GBS & +EMD & $+\mathrm{NO}$ & Re-base \\
\hline $\mathrm{pH}$ & $7.48 \pm 0.02$ & $7.51 \pm 0.02$ & $7.50 \pm 0.02$ & $7.50 \pm 0.02$ & $7.51 \pm 0.02$ \\
\hline $\mathrm{PaO}_{2}$ & $82 \pm 3$ & $67 \pm 6$ & $55 \pm 6$ & $58 \pm 8$ & $59 \pm 3$ \\
\hline $\mathrm{PaCO}_{2}$ & $39 \pm 2$ & $44 \pm 2$ & $42 \pm 1$ & $41 \pm 1$ & $37 \pm 2$ \\
\hline $\mathrm{HCO}_{3}$ & $29 \pm 2$ & $35 \pm 3$ & $33 \pm 2$ & $32 \pm 3$ & $30 \pm 3$ \\
\hline $\mathrm{SaO}_{2}$ & $97 \pm 0.3$ & $94 \pm 1.6$ & $89 \pm 3.5$ & $90 \pm 3$ & $93 \pm 0.9$ \\
\hline
\end{tabular}

Base = baseline at beginning; Hyp = hypoxia; GBS = GBS infusion; + EMD/BQ610 = following maximal dose of EMD122946 or BQ 610 , continued hypoxia or GBS; +NO = following $20 \mathrm{ppm} \mathrm{NO}$, continued hypoxia/GBS; Re-base = return to room air, without NO or hypoxia/GBS (mean \pm SEM; $n=6$; $* p<0.05$ vs. Hyp by Tukey's multiple comparison test performed when $p<0.05$ by Repeated Measures ANOVA). 
Table 2. Arterial blood gas analysis in the hypoxia/GBS models with BQ 610

\begin{tabular}{|c|c|c|c|c|c|}
\hline & Base & Нур & +BQ610 & $+\mathrm{NO}$ & Re-base \\
\hline \multicolumn{6}{|c|}{ BQ 610-hypoxia model } \\
\hline $\mathrm{pH}$ & $7.47 \pm 0.01$ & $7.50 \pm 0.02$ & $7.55 \pm 0.03$ & $7.56 \pm 0.02$ & $7.49 \pm 0.02$ \\
\hline $\mathrm{PaO}_{2}$ & $78 \pm 7^{*}$ & $25 \pm 1$ & $26 \pm 1$ & $24 \pm 1$ & $73 \pm 5^{*}$ \\
\hline $\mathrm{HCO}_{3}$ & $30 \pm 2$ & $25 \pm 2$ & $26 \pm 1$ & $25 \pm 1$ & $27 \pm 2$ \\
\hline \multirow[t]{2}{*}{$\mathrm{SaO}_{2}$} & $96 \pm 1^{*}$ & $52 \pm 4$ & $58 \pm 2$ & $56 \pm 4$ & $96 \pm 1^{*}$ \\
\hline & Base & GBS & +BQ610 & $+\mathrm{NO}$ & Re-base \\
\hline $\mathrm{pH}$ & $7.45 \pm 0.02$ & $7.48 \pm 0.02$ & $7.45 \pm 0.02$ & $7.45 \pm 0.02$ & $7.46 \pm 0.02$ \\
\hline $\mathrm{PaO}_{2}$ & $97 \pm 4$ & $90 \pm 6$ & $54 \pm 5^{*}$ & $68 \pm 7$ & $60 \pm 7 *$ \\
\hline $\mathrm{PaCO}_{2}$ & $39 \pm 1$ & $36 \pm 2$ & $38 \pm 2$ & $39 \pm 4$ & $37 \pm 2$ \\
\hline $\mathrm{HCO}_{3}$ & $27 \pm 2$ & $27 \pm 1$ & $27 \pm 1$ & $27 \pm 1$ & $26 \pm 1$ \\
\hline $\mathrm{SaO}_{2}$ & $98 \pm 0.4$ & $97 \pm 0.5$ & $87 \pm 5$ & $93 \pm 1.6$ & $90 \pm 3.2$ \\
\hline
\end{tabular}

Base = baseline at beginning; Hyp = hypoxia; GBS = GBS infusion; + EMD/BQ610 = following maximal dose of EMD122946 or BQ 610, continued hypoxia or GBS; $+\mathrm{NO}=$ following $20 \mathrm{ppm} \mathrm{NO}$, continued hypoxia/GBS; Re-base $=$ return to room air, without NO or hypoxia/GBS $(\mathrm{mean} \pm \mathrm{SEM} ; n=6$; $* p<0.05$ vs. Hyp by Tukey's multiple comparison test performed when $p<0.05$ by Repeated Measures (ANOVA).

Table 3. Endothelin levels (in pg/ml of plasma) in the Hypoxia and GBS models with EMD 122946 and BQ610

\begin{tabular}{lccccc}
\hline & Base & $\begin{array}{c}\text { Hypoxia or GBS } \\
\text { infusion }\end{array}$ & +EMD/BQ610 & Ro & Re-base \\
\hline Hypoxia model & $0.27 \pm 0.07$ & $0.39 \pm 0.10$ & $0.72 \pm 0.19$ & $0.86 \pm 0.18$ & $0.54 \pm 0.23$ \\
GBS model & $0.48 \pm 0.11$ & $0.26 \pm 0.11$ & $0.76 \pm 0.52$ & $0.55 \pm 0.15$ & $1.05 \pm 0.32$ \\
\hline
\end{tabular}

Base $=$ baseline at beginning of experiment $+\mathrm{EMD} / \mathrm{BQ} 610=$ following maximal dose EMD 122946 or BQ 610 , continued hypoxia/GBS infusion; $+\mathrm{NO}=$ following $20 \mathrm{ppm} \mathrm{NO}$, continued hypoxia/GBS infusion; Re-base = completed hypoxia/GBS infusion and off NO (mean \pm SEM; $n=7 ; p<0.05$ by repeated measures ANOVA for hypoxia model; $p=0.17$ for GBS model).

why $\mathrm{ET}_{\mathrm{A}}$ blockade is not effective in attenuating GBS-induced pulmonary hypertension. Complex interactions are known to occur between the endothelin, thromboxane, and nitric oxide systems. For example, activation of endothelin-B receptors by ET-1 is known to release NO (a vasodilator), and also release thromboxane A2 (a vasoconstrictor) (22). There is evidence that there may be at least two types of ET-B receptor subtypes expressed in the pulmonary circulation, one mediating vasoconstriction, which cannot be blocked by the compound BQ788, and one mediating vasodilation, which can be affected by BQ788 (23). Thromboxane A2 mimetics have also been seen to regulate ET-1 synthesis in some cell lines (24). ET $\mathrm{A}_{\mathrm{A}}$ receptor blockers have been shown to be effective in attenuating endotoxin-induced pulmonary hypertension and shock in a porcine (25) and a sheep model (26), although without influencing elevated thromboxane levels (26). However, our study used piglets $<1$ mo of age, and it is well known that the hemodynamic effects of ET-1 are dependent on postnatal age (27). Therefore, it is possible that our study can be extrapolated to human infants, but perhaps not to adults.

We have previously shown in the same model that inhaled NO decreases PAP and PVRI back to baseline in both acute hypoxia-and GBS-induced pulmonary hypertension (28). However, we now observed that following treatment with $\mathrm{ET}_{\mathrm{A}}$ receptor blockers, NO was only partially effective in reducing PAP and PVRI in the GBS model, but decreased PAP and PVRI to baseline or below in the hypoxia model. This suggests that $\mathrm{ET}_{\mathrm{A}}$ blockade partially inhibits in some way the effects of inhaled NO in the GBS model, although this explanation appears counterintuitive. Although it would be interesting to know why $\mathrm{ET}_{\mathrm{A}}$ blockers are effective in hypoxia and endotox- in-induced pulmonary hypertension but not in GBS-induced pulmonary hypertension, and why $\mathrm{ET}_{\mathrm{A}}$ blockade interferes with the response to inhaled NO, this study was not designed to investigate underlying mechanisms in detail but rather explore the potential therapeutic role of these agents.

As expected, the response to hypoxia was different in the pulmonary and systemic vascular beds. Hypoxia caused an increase in pulmonary vascular resistance and a decrease in systemic vascular resistance, thus indicating that different mechanisms regulate these effects in the porcine model. As $\mathrm{ET}_{\mathrm{A}}$ blockade attenuated only pulmonary vascular resistance and did not change systemic vascular resistance significantly, and furthermore did not affect baseline pulmonary or systemic vascular resistance, it is unlikely that $\mathrm{ET}_{\mathrm{A}}$ receptors played a significant role in modulation of baseline pulmonary or systemic vascular resistances, or of hypoxia-induced changes in systemic vascular resistance in our model. Our results are roughly similar to those of Medbo et al. who investigated the effects of SB 217242 (a combined $\mathrm{ET}_{\mathrm{A}}$ and $\mathrm{ET}_{\mathrm{B}}$ blocker) when used as prophylaxis in acutely instrumented and mechanically ventilated 1- to 2-d-old hypoxic piglets and showed that ET receptor blockade attenuated pulmonary vasoconstriction during hypoxemia and reoxygenation (17). However, our study differs from that of Medbo et al. (17) as we used older chronically instrumented spontaneously breathing piglets that received $\mathrm{ET}_{\mathrm{A}}$ receptor-specific blockers, after the onset of hypoxia rather than as prophylaxis.

EMD 122946 did not significantly reduce PAP when LNAME was given but ameliorated hypoxia-induced $\mathrm{PH}$. We speculate based on the observations that hypoxia and L-NAME induce $\mathrm{PH}$ by decreasing NO production. Subsequently, in the 
presence of $\mathrm{ET}_{\mathrm{A}}$ receptor blockade, there is a shift toward more $\mathrm{ET}_{\mathrm{B}}$ activation which releases $\mathrm{NO}$ and subsequent NOmediated reversal of hypoxic $\mathrm{PH}$. Such a shift toward increased $\mathrm{NO}$ following $\mathrm{ET}_{\mathrm{B}}$ activation would not be expected to occur in animals pretreated with L-NAME. Support for this speculation comes from the recent work of Perreault et al. (29) who showed that $\mathrm{ET}_{\mathrm{A}}$ blockade restored exhaled $\mathrm{NO}$ concentrations in hypoxic piglets to levels seen in normoxic piglets. However, Perreault et al. used a chronic hypoxic piglet model, rather than an acute hypoxia model (29). These authors also observed dilator responses to the NO donor SIN-1 added to the perfusion bath of the isolated perfused lung, rather than inhaled NO as in our study.

Nelin et al. (30) showed that hypoxia decreased NO production in the isolated perfused neonatal pig lung and increased perfusion pressure, which supports our speculation that reduced NO production contributes to acute hypoxic $\mathrm{PH}$. In their study, L-NAME also increased perfusion pressure and decreased NO production, as expected. However, L-NAME potentiated hypoxia effects in their study but not in ours. In the study by Nelin et al. the $\mathrm{P}_{\mathrm{O} 2}$ of the perfusate during hypoxic conditions was $52+1$ torr, while the arterial $\mathrm{P}_{\mathrm{O} 2}$ was $26-27$ torr in our study (Table 1), which corresponds to large differences in oxygen saturation and therefore oxygen delivery. It is possible that in the study by Nelin et al. the lungs were not sufficiently hypoxic to strongly inhibit NO production, and that subsequent L-NAME was able to inhibit NO production even further. This is only one possible explanation for the difference in the models. It is difficult to compare isolated lung models to whole animal models, as other factors e.g. cardiac output, release of atrial natriuretic peptide (a pulmonary vasodilator) from the heart, and other variables affect pulmonary hemodynamics.

Differences in in vivo effects were also found between the two drugs used, although both agents were designed as selective endothelin-A receptor antagonists. BQ-610 (Homopiperidinyl-CO-Leu-D-Trp(CHO)-D-Trp-OH) has been used by many other investigators as a selective ETA blocker. BQ 610 has an $\mathrm{IC}_{50}(\mathrm{nM})$ for $\mathrm{ET}_{\mathrm{A}}$ binding at 0.64 and for $\mathrm{ET}_{\mathrm{B}}$ binding at 24000 , resulting in a $\mathrm{ET}_{\mathrm{B}} / \mathrm{ET}_{\mathrm{A}} \mathrm{IC}_{50}$ ratio of 37500 (personal communication from Thukuba Research Institute, Banyu Pharmaceutical Co., Ltd). EMD 122946 (a benzothiadiazole derivative) was recently developed by Merck as a highly selective $\mathrm{ET}_{\mathrm{A}}$ blocker (31), with an $\mathrm{IC}_{50}(\mathrm{nM})$ for $\mathrm{ET}_{\mathrm{A}}$ binding at 0.032 and for $\mathrm{ET}_{\mathrm{B}}$ binding at $160\left(\mathrm{ET}_{\mathrm{B}} / \mathrm{ET}_{\mathrm{A}} \mathrm{IC}_{50}\right.$ ratio 5000). After IV administration EMD 122946 has rapid onset of action and quick clearance within hours (31), and these characteristics are roughly comparable to those of BQ 610 . Our study revealed that a $2 \mathrm{mg} / \mathrm{kg}$ i.v. bolus of EMD 122946 was equipotent to $0.25 \mathrm{mg} / \mathrm{kg}$ of BQ 610 in the acute hypoxia model in regard to lowering of PAP and PVRI. However, it is not clear why this equipotent dose had different effects in the GBS model, when BQ 610 (but not EMD 122946) elevated PAP and PVRI. The effects of these two agents on $\mathrm{ET}_{\mathrm{B} 2}\left(\mathrm{ET}_{\mathrm{B}}\right.$ constictor) receptors have not been described, although it is suspected that selective $\mathrm{ET}_{\mathrm{A}}$ antagonists such as these agents do not bind to $\mathrm{ET}_{\mathrm{B}}$ constictor receptors as they do not abolish the pressor response to ET-1 (31). Both agents are known to be active at the range of $\mathrm{pH}$ (7.3-7.7) that was noted in the piglets during the experiments. As noted in the results, hypoxia led to an increase in cardiac output and a decrease in SVRI, while GBS did not change cardiac output or SVRI significantly. In the GBS model, BQ 610 led to an increase in PVRI with a lesser change in PAP indicating impaired cardiac output. It is possible that these cardiac effects contribute to differences between EMD 122946 and BQ 610, as well as possible differences in binding to $\mathrm{ET}_{\mathrm{B} 2}$ receptors. Although the difference in physiologic effects between EMD 122946 and BQ 610 cannot be explained readily, the clinical significance of our observation of interdrug differences is that careful selection of an appropriate $\mathrm{ET}_{\mathrm{A}}$ blocker is essential before beginning human trials.

We observed that plasma ET-1 levels do not increase significantly with hypoxia but show an increasing trend with $\mathrm{ET}_{\mathrm{A}}$ blockade, both in the hypoxia and GBS models. This is consistent with results obtained by us and other investigators, who have seen that although ET-1 levels increase with acute hypoxia in adult rats (14), they either decrease (32) or show no change (33) in piglets, suggesting primarily a paracrine rather than endocrine action. The increase in ET-1 levels with receptor blockade may be an indicator of $\mathrm{ET}_{\mathrm{A}}$ - receptor occupation by the antagonist and decreased clearance of circulating ET-1, although it is considered that a low capacity saturable $\mathrm{ET}_{\mathrm{B}}$-receptor-mediated mechanism is mostly responsible for clearance (34). Inter-species differences also probably exist in the role of ET-1 in hypoxic pulmonary hypertension. Wong et al. (35) showed that the $\mathrm{ET}_{\mathrm{A}}$ receptor antagonist $\mathrm{BQ} 123$ did not reduce acute hypoxic pulmonary vasoconstriction in intact newborn lambs, although this study and others have shown that $\mathrm{ET}_{\mathrm{A}}$ receptor antagonists are effective in similar rat $(14,15)$ and porcine models $(17,36)$. It is probable that ET-1 is also involved in human neonatal pulmonary hypertension, for it has been observed that circulating ET-1 levels are elevated in newborn infants with PPHN, are positively correlated with disease severity, and decline with resolution of disease in patients who do not require extracorporeal membrane oxygenation (only 2 of the 24 infants in this study had sepsis, the majority had aspiration syndromes) (7). Another study comparing 20 infants with PPHN to 20 normal term infants also showed that ET-1 was elevated in PPHN and correlated with disease severity (8). Therefore, it is possible that $\mathrm{ET}_{\mathrm{A}}$ receptor blockade could prove to be of benefit in human infants with PPHN.

\section{CONCLUSIONS}

In conclusion, this study has shown that selective $\mathrm{ET}_{\mathrm{A}}$ receptor blockade can attenuate acute hypoxic pulmonary hypertension in a piglet model, and that selective $\mathrm{ET}_{\mathrm{A}}$ receptor blockade is either ineffective or may worsen acute GBS induced pulmonary hypertension. $\mathrm{ET}_{\mathrm{A}}$ receptor antagonists are currently undergoing clinical trials and have shown promising results in human adults with hypertension and congestive heart failure $(37,38)$. Further study is required to evaluate these agents in chronic pulmonary hypertension and vascular remodeling in neonatal and juvenile whole animal models, and to establish safety and appropriate dosing. Subsequent clinical trials may then be performed in carefully selected neonates and infants with pulmonary hypertension of noninfectious etiology. 
Acknowledgments. EMD122946 was provided by Merck KGaA, Darmstadt, Germany.

\section{REFERENCES}

1. Walsh-Sukys MC 1993 Persistent pulmonary hypertension of the newborn. The black box revisited. Clin Perinatol 20:127-143

2. Goodman G, Perkin RM, Anas NG, Sperling DR, Hicks DA, Rowen M 1988 Pulmonary hypertension in infants with bronchopulmonary dysplasia. J Pediatr 112:67-71

3. Wong J, Vanderford PA, Fineman JR, Chang R, Soifer SJ 1993 Endothelin-1 produces pulmonary vasodilation in the intact newborn lamb. Am J Physiol 265:H1318-1325

4. Bradley LM, Czaga JF, Goldstein RE 1990 Circulatory effects of endothelin-1 in newborn piglets. Am J Physiol 259:H1613-1617

5. Barnard JW, Barman SA, Adkins WK, Longnecker GL, Taylor AE 1991 Sustained effects of endothelin-1 on rabbit, dog, and rat pulmonary circulation. Am J Physiol 261:H479-486

6. Ziegler JW, Ivy DD, Kinsella JP, Abman SH 1995 The role of nitric oxide, endothelin, and prostaglandins in the transition of the pulmonary circulation. Clin Perinatol 22:387-402

7. Rosenberg AA, Kennaugh J, Koppenhafer SL, Loomis M, Chatfield BA, Abman SH 1993 Elevated immunoreactive endothelin-1 levels in newborn infants with persistent pulmonary hypertension. J Pediatr 123:109-114

8. Kumar P, Kazzi NJ, Shankaran S 1996 Plasma immunoreactive endothelin-1 concentrations in infants with persistent pulmonary hypertension of the newborn. Am J Perinatol 13:335-341

9. Macdonald PD, Paton RD, Logan RW, Skeoch CH, Davis CF 1999 Endothelinlevels in infants with pulmonary hypertension receiving extracorporeal membrane oxygenation. J Perinat Med 27:216-220

10. Allen SW, Chatfield BA, Koppenhafer SA, Schaffer MS, Wolfe RR, Abman SH 1993 Circulating immunoreactive endothelin-1 in children with pulmonary hypertension. Association with acute hypoxic pulmonary vasoreactivity. Am Rev Respir Dis 148:519-522

11. Noguchi Y, Hislop AA, Haworth SG 1997 Influence of hypoxia on endothelinbinding sites in neonatal porcine pulmonary vasculature. Am J Physiol 272:H669678

12. Soukka H, Jalonen J, Kero P, Kaapa P 1998 Endothelin-1, atrial natriuretic peptide and pathophysiology of pulmonary hypertension in porcine meconium aspiration. Acta Paediatr 87:424-428

13. Wong J, Reddy VM, Hendricks-Munoz K, Liddicoat JR, Gerrets R, Fineman JR 1995 Endothelin-1 vasoactive responses in lambs with pulmonary hypertension and increased pulmonary blood flow. Am J Physiol 269:H1965-1972

14. Oparil S, Chen SJ, Meng QC, Elton TS, Yano M, Chen YF 1995 Endothelin-A receptor antagonist prevents acute hypoxia-induced pulmonary hypertension in the rat. Am J Physiol 268:L95-100

15. Tilton RG, Munsch CL, Sherwood SJ, Chen SJ, Chen YF, Wu C, Block N, Dixon RA, Brock TA 2000 Attenuation of pulmonary vascular hypertension and cardiac hypertrophy with sitaxsentan sodium, an orally active ET(A) receptor antagonist. Pulm Pharmacol Ther 13:87-97

16. DiCarlo VS, Chen SJ, Meng QC, Durand J, Yano M, Chen YF, Oparil S 1995 ETA-receptor antagonist prevents and reverses chronic hypoxia-induced pulmonary hypertension in rat. Am J Physiol 269:L690-697

17. Medbo S, Tollofsrud PA, Saugstad OD 1999 Pulmonary hemodynamics in newborn piglets during hypoxemia and reoxygenation: blocking of the endothelin-1 receptors. Pediatr Res 46:514-522
18. Tarpey MN, Graybar GB, Lyrene RK, Godoy G, Oliver J, Gray BM, Philips III JB 1987 Thromboxane synthesis inhibition reverses group B Streptococcus-induced pulmonary hypertension. Crit Care Med 15:644-647

19. Philips JB, Li JX, Gray BM, Pritchard DG, Oliver JR 1992 Role of capsule in pulmonary hypertension induced by group B streptococcus. Pediatr Res 31:386-390

20. LeCras TD, McMurtry IF 2001 Nitric oxide production in the hypoxic lung. Am J Physiol Lung Cell Mol Physiol 280:L575-582

21. Villamor E, Perez Vizcaino F, Tamargo J, Moro M 1996 Effects of group B Streptococcus on the responses to U46619, endothelin-1, and noradrenaline in isolated pulmonary and mesenteric arteries of piglets. Pediatr Res 40:827-833

22. Vila JM, Medina P, Segarra G, Aldasoro M, Noguera I, Lluch S 2001 Endothelin1 -induced potentiation of adrenergic responses in the rabbit pulmonary artery: role of thromboxane A(2). Eur J Pharmacol 413:247-254

23. Schmect J, Krafft P, Groschler A, Heller A, Neuhof H, van Ackern K, Koch T 1999 Characterization and distribution of endothelin receptors in the pulmonary circulation: investigation of isolated, perfused, and ventilated rabbit lungs. Shock 12:247-254

24. Chua CC, Hamdy RC, Chua BH 1996 Regulation of endothelin-1 production by a thromboxane A2 mimetic in rat heart smooth muscle cells. Biochim Biophys Acta 1313:1-5

25. Wanecek M, Oldner A, Rudehill A, Sollevi A, Alving K, Weitzberg E 1999 Endothelin(A)-receptor antagonism attenuates pulmonary hypertension in porcine endotoxin shock. Eur Respir J 13:145-151

26. Snapper JR, Thabes JS, Lefferts PL, Lu W 1998 Role of endothelin in endotoxininduced sustained pulmonary hypertension in sheep. Am J Respir Crit Care Med $157: 81-88$

27. Wong J, Vanderford PA, Fineman JR, Soifer SJ 1994 Developmental effects of endothelin-1 on the pulmonary circulation in sheep. Pediatr Res 36:394-401

28. Ambalavanan N, St. John E, Carlo WA, Bulger A, Philips JB III 2002 Feasibility of nitric oxide administration by oxygen hood in neonatal pulmonary hypertension. J Perinatol 22:50-56

29. Perreault T, Berkenbosch JW, Barrington KJ, Decker ER, Wu C, Brock TA, Baribeau J 2001 TBC3711, an ET(A) receptor antagonist, reduces neonatal hypoxia-induced pulmonary hypertension in piglets Pediatr Res 50:374-383

30. Nelin LD, Thomas CJ, Dawson CA 1996 Effect of hypoxia on nitric oxide production in neonatal pig lung. Am J Physiol 271:H8-14

31. Mederski WW, Dorsch D, Osswald M, Anzali S, Christadler M, Schmitges CJ, Schelling P, Wilm C, Fluck M 1998 Endothelin antagonists: discovery of EMD 122946, a highly potent and orally active ETA selective antagonist. Bioorg Med Chem Lett 8:1771-1776

32. Medbo S, Yu XQ, Asberg A, Saugstad OD 1998 Pulmonary hemodynamics and plasma endothelin-1 during hypoxemia and reoxygenation with room air or $100 \%$ oxygen in a piglet model. Pediatr Res 44:843-849

33. Perreault T, Stewart DJ, Cernacek P, Wu X, Ni F, De Marte J, Giaid A 1993 Newborn piglet lungs release endothelin-1: effect of alpha-thrombin and hypoxia. Can J Physiol Pharmacol 71:227-233

34. Burkhardt M, Barton M, Shaw SG 2000 Receptor- and non-receptor-mediated clearance of big-endothelin and endothelin-1: differential effects of acute and chronic ETA receptor blockade. J Hypertens 18:273-279

35. Wong J, Vanderford PA, Winters JW, Chang R, Soifer SJ, Fineman JR 1993 Endothelin-1 does not mediate acute hypoxic vasoconstriction in the intact newborn lamb. J Cardiovasc Pharmacol 22:S262-266

36. Holm P, Liska J, Franco-Cereceda A 1998 The ETA receptor antagonist, BMS182874 , reduces acute hypoxic pulmonary hypertension in pigs in vivo. Cardiovasc Res 37:765-771

37. Luscher TF, Barton M 2000 Endothelins and endothelin receptor antagonists: therapeutic considerations for a novel class of cardiovascular drugs. Circulation 102:24342440

38. Love MP, McMurray JJ 2001 Endothelin receptor antagonists and cardiovascular diseases of aging. Drugs Aging 18:425-440 